\title{
AS PERDAS TERRITORIAIS DO ESTADO BOLIVIANO (1825-1935)
}

\author{
Fernando Siliano Reyes*
}

\section{RESUMO:}

O presente artigo versa sobre a constituição do Estado boliviano e suas perdas territoriais no período compreendido entre sua fundação, em 1825, até o término da Guerra do Chaco, em 1935. Essas perdas territoriais não só diminuem o tamanho do território boliviano como tolhem as perspectivas de circulação desse país, que tenta minimizar tais perdas com acordos de uso territorial exatamente com aqueles países que Ihe tomaram o território. Para compreendermos esse percurso, iniciamos o artigo descrevendo a formação populacional e territorial da Bolívia, desde as populações pré-colombianas, principalmente os Quechuas e os Aymaras, e a posterior ocupação espanhola, sempre levando em conta que a Bolívia é dotada de uma historicidade própria e inserida de forma específica na ordem do capital mundializado. Na sequência, são discutidas as sucessivas guerras travadas entre a Bolívia e três países vizinhos (Chile, Brasil e Paraguai), que culminaram em significativas perdas territoriais para o Estado boliviano.

\section{PALAVRAS CHAVE:}

Bolívia - circulação - conflito - geopolítica - território

\section{ABSTRACT:}

The present study approaches the constitution of the Bolivian State and its territorial losses since its foundation in 1825 until the end of the Chaco War in 1935. Not only did such losses diminish the size of this Bolivian State's territory but also restrained the country's circulation perspectives. The country has tried to minimize its losses through international agreements on territorial use with exactly those neighbors which have taken part of its territory. To understand this process, the present study describes Bolivia's populational and territorial formation, beginning with pre-Colombian peoples, mainly the Quechuas and the Aymaras, followed by the Spanish occupation, taking into account the fact that Bolivia has its own plentiful historicity, and is specifically inserted in the order of the world capital. Last but not least, this paper discusses the successive wars fought against three neighbor countries Chile, Brazil and Paraguay - which resulted in significant territorial loss to the Bolivian State.

\section{KEY WORDS:}

Bolivia - circulation - conflict - geoplitics - territory

A nação boliviana, para o senso comum e a indústria cultural, tem sido sinônimo de pobreza e miséria e, nos últimos tempos, uma miséria de feições nitidamente indígenas e de experimentos populistas. Segundo Hofmeister (2004), a Bolívia pode ser considerada o país mais pobre da
América do Sul e o país com maior instabilidade política do continente. Desde a independência, em 1825, pode-se contar mais de 200 golpes e trocas de governo com uso de força. Constatações importantes sobre o "estado das coisas" na Bolívia. 
Contudo, o conhecimento não se faz apenas por constatações e sim pelo avanço da análise do real, que precisa ser desvelado, ou seja, desnaturalizado e historicizado Portanto, o que a Bolívia é (assim como qualquer sociedade) não é o ponto de chegada da reflexão geográfica e sim o ponto de partida para a compreensão de uma intrincada relação, de uma sociedade nacional com o espaço e o tempo do capitalismo mundializado.

Ao longo da história da Bolívia diversos acontecimentos perpetuaram uma situação de exploração das classes subalternas que se refletiram no espaço geográfico, gerando um processo conhecido como Desenvolvimento Desigual e Combinado no território boliviano, onde porções do território, em determinados períodos históricos, foram apropriadas por forças hegemônicas dentro do escopo do Modo de Produção Capitalista, sendo valorizadas em virtude de seu intrínseco valor de uso.

A República da Bolívia é um dos países mais pobres do continente americano. Possui uma área de $1.098 .581 \mathrm{~km}^{2}$ e se limita ao norte e a leste com o Brasil, ao sul com a Argentina, a oeste com o Peru, a sudeste com o Paraguai e a sudoeste com o Chile (Figura 1).

Segundo dados do Instituto Nacional de Estadística ${ }^{1}$, órgão do governo boliviano, o território desse país é dividido em três grandes zonas geográficas. A de maior extensão é chamada de llanos, que abarca cerca de $59 \%$ do território boliviano (aproximadamente 648.000 $\mathrm{km}^{2}$ ) e localiza-se ao norte da Cordilheira Oriental, estendendo-se desde a base da Cordilheira dos Andes até o rio Paraguai. Nesta zona predominam as planícies, que possuem uma vegetação exuberante. Em seguida se destaca a Zona Andina, com cerca de $28 \%$ do território nacional (aproximadamente $307.000 \mathrm{~km}^{2}$ ). Encontra-se a mais de 3000 metros de altitude, entre as Cordilheiras Ocidental e Oriental. É nessa área que se encontra o lago mais alto do mundo, o Titicaca, situado a 3810 metros de altitude e com uma extensão de $8100 \mathrm{~km}^{2}$. Por fim, a Zona Subandina, intermediária entre o altiplano e os llanos (planícies) orientais que abarca 13\% do território da Bolívia, onde se encontra os vales andinos e os yungas (uma zona de transição entre as terras altas, secas e áridas, e terras baixas e úmidas), a aproximadamente 2500 metros de altitude.

O Estado boliviano é dividido em nove departamentos (Pando, Beni, Santa Cruz, Chuquisaca, Tarija, Potosi, Cochabamba, Oruro e La Paz) (Figura 2).

Segundo o Censo Boliviano de 2001, 59\% da população boliviana $(4,7$ milhões) é composta por pobres, cerca de $64 \%$ são indígenas (a maioria quéchua e aymará) ${ }^{2}$, concentradas, até a década de 1980 nas áreas rurais. Porém, apesar de serem descendentes diretos dos primeiros ocupantes do atual território boliviano, essa população está a mercê dos interesses econômicos e políticos da burguesia nacional e do imperialismo, ora britânico ora estadunidense, e atualmente de capitalistas brasileiros, argentinos, croatas e japoneses, que vislumbram a Bolívia como um espaço de acumulação de capital. Não pelo fato de serem indígenas, mas porque são efetivamente pobres e compõem, dentro do Modo Capitalista de Produção, seu papel de classe explorada.

Na região andina há resquícios de civilização de cerca de 20.000 anos, mas segundo KLEIN (2004), a primeira grande civilização a se desenvolver no altiplano boliviano foi a civilização Tiahuanaco, que tinha como capital a cidade homônima, erguida na margem sul do lago Titicaca, a partir do ano 600 a.C, desenvolvendo técnicas agrícolas de cultivo em terraços, nos planaltos, até desaparecer por volta de 1.200 d.C.

Posteriormente à civilização Tiahuanaco, desenvolveu-se próximo ao Lago Titicaca o reino dos Aymaras, que migraram para Tiahuanaco após sua derrocada. Os Aymaras eram divididos em sete grandes nações. Segundo KLEIN (2004, p. 14),

"O desenvolvimento dos reinos dos Aymaras assinalou propriamente o início da história boliviana. Eles dominaram os planaltos centrais desde o fim do século XII até a chegada dos espanhóis no século XVI". 
Figura 1: Mapa atual da Bolívia

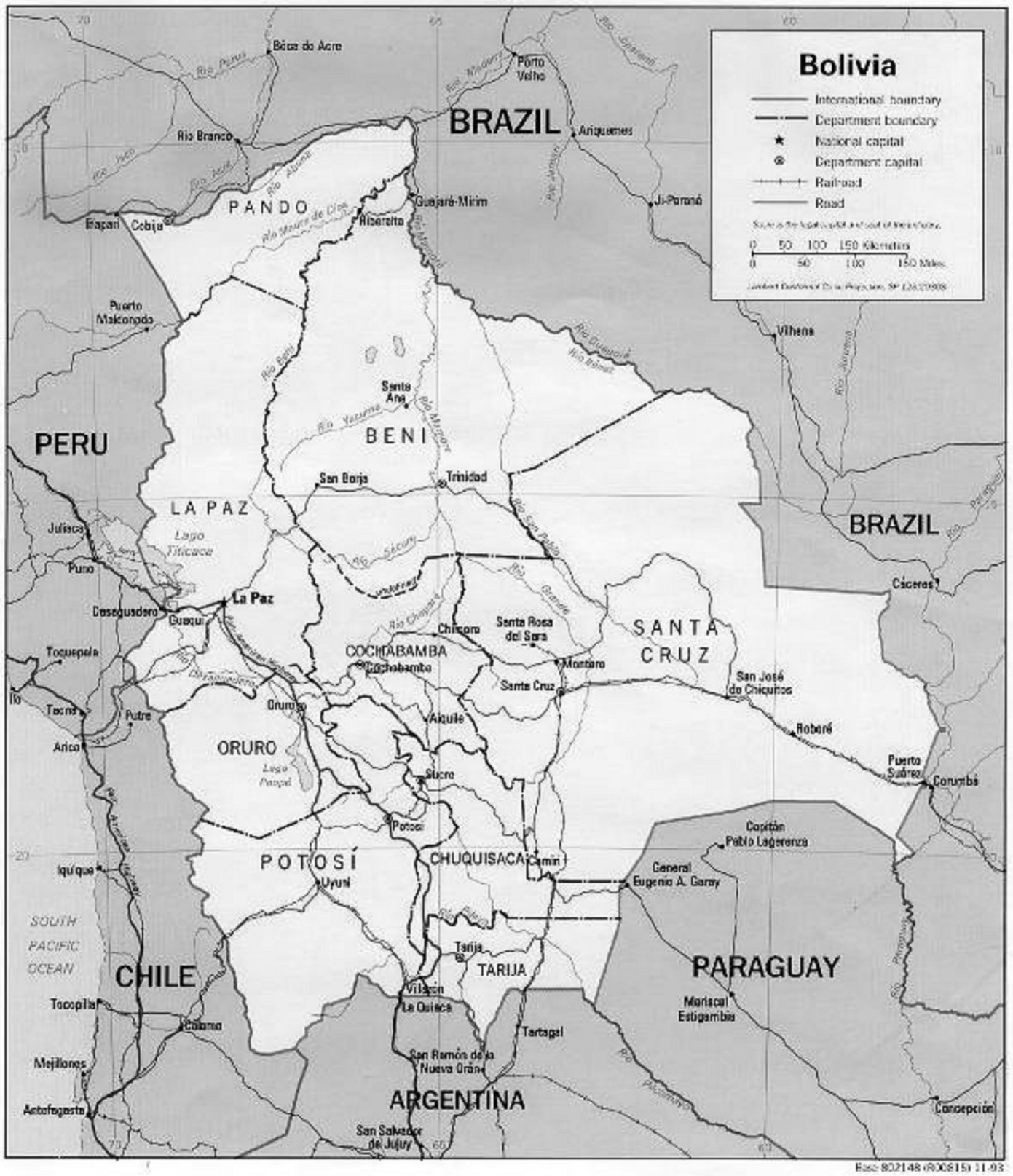

Fonte: www.libreria.com.br/imagens/mapas/bolivia.jpg. Acessado em 16/08/2008 
Figura 2: Departamentos bolivianos

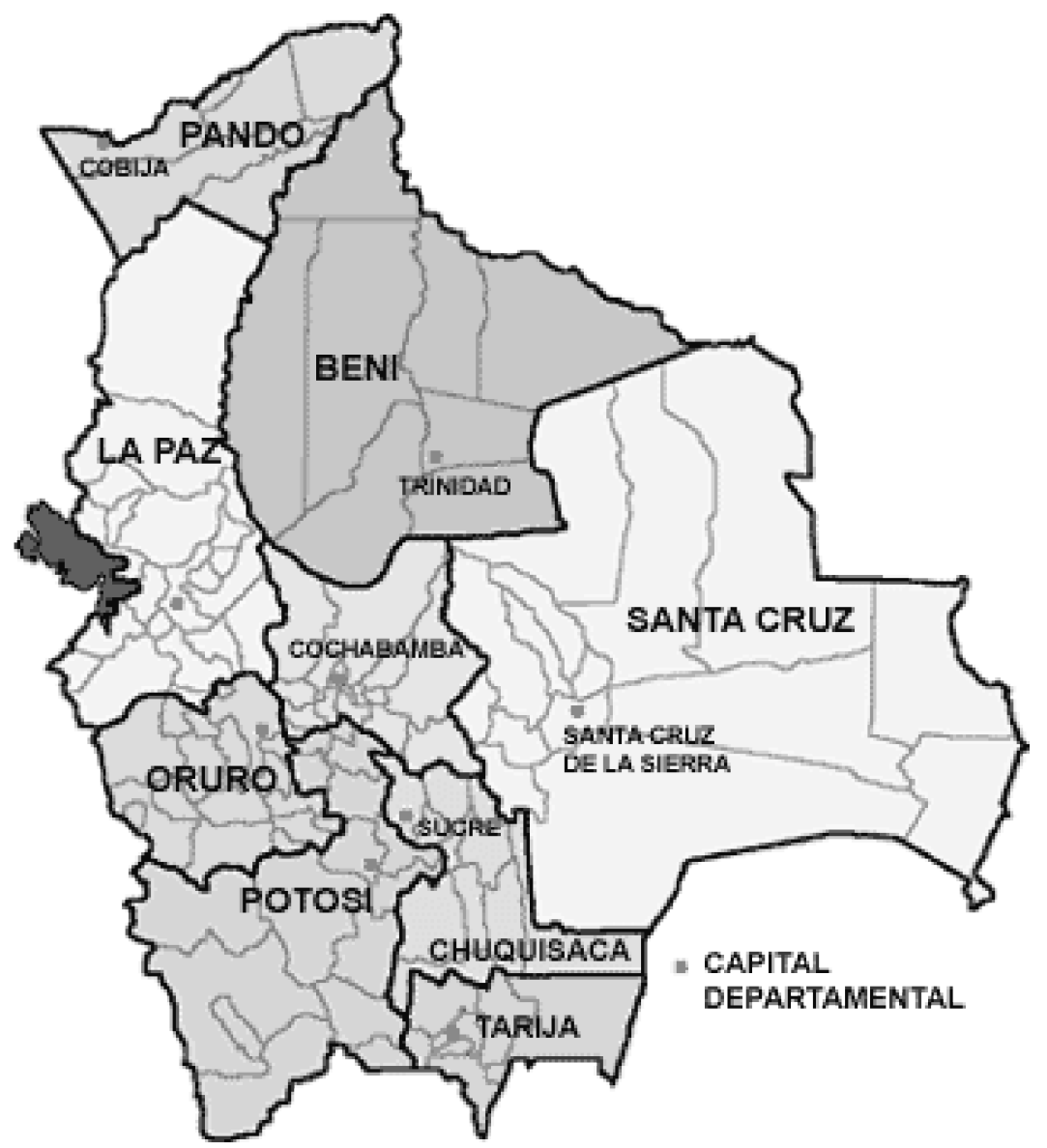

Fonte: www.boliviacultura.com/images/mapa_dept2.jpg (Acessado em 14/08/2008)

Dedicavam-se principalmente à criação de Ihamas e alpacas, e praticavam uma agricultura extensiva.

Os Quechuas também emergiram após o colapso da civilização Tiahuanaco. O Império Inca $^{3}$, emergido em Cuzco, ao contrário dos aymarás, era expansionista e estendeu seu império desde o sul da atual Colômbia até o norte do atual Chile.

Os Quechuas estenderam a influência de seu império sobre o reino dos Aymaras, em 1460, confinando-os em uma província de nome Kollasuyo, uma das quatro unidades administrativas do Império Inca. Segundo Klein, essa influência não significou a incorporação dos Aymaras, que mantiveram sua organização social e política e apenas pagavam tributos aos Quechuas. A derrocada dos Aymaras aconteceu em 1470, porém, não de modo pacífico. Derrotados, os Aymaras perderam a independência para os Quechuas, porém, a língua aymara não conseguiu ser derrotada e é utilizada até hoje. 
A população pré-colombiana, que ocupava as planícies do leste, era composta em sua maioria por índios, que falavam o idioma guarani, principalmente das etnias Moxo e Chiquitanos. Os povos do leste não foram dominados pelo Império Inca, mas, por outro lado, os espanhóis tiveram enormes dificuldades em dominá-los. Segundo informações contidas no sítio do Instituto Nacional de Estadística da Bolívia ${ }^{4}$, apenas em 1675 dois padres espanhóis partiram de Lima até Santa Cruz e de Santa Cruz para a tribo dos moxos em Guapay, fundando, em 1682, a missão de Nossa Senhora do Loreto e em 1686 fundaram a missão da Santíssima Trindade que hoje é a capital do departamento de Beni. Ainda segundo o Instituto Nacional de Estadística, os padres jesuítas levantaram a primeira construção nas terras dos chiquitanos, fundando São Francisco Xavier, nas proximidades do rio Paraguai.

\section{A Ocupação Espanhola}

A conquista espanhola do Império Inca foi obra de Francisco Pizarro, numa época de declínio do império. Após a morte do imperador Huayna Capac em 1527, seus filhos Huascar e Atahualpa travaram uma briga pela sucessão.

De acordo com CHASTEEN (2001, p. 45),

"Pizarro tinha apenas 168 espanhóis, mas infelizmente para os incas, o imperador reinante e seu sucessor haviam morrido subitamente da epidemia que, alastrando-se pelas rotas comerciais à frente de Pizarro, devastou a família dirigente inca, gerando uma crise de sucessão pouco antes da chegada dos espanhóis. Desastradamente, uma guerra civil inca havia eclodido. Atahualpa comandava um lado e seu irmão, Huascar, o outro. O ardiloso Pizarro conseguiu jogar os dois lados um contra o outro, obtendo a derradeira vitória para si."

Embora Atahualpa tenha derrotado Huascar, não havia ainda consolidado plenamente seu poder quando da chegada dos espanhóis em 1532.

Entre os Aymarás também houve resistência à ocupação espanhola, porém, a tarefa se mostrou bastante difícil, pois além de enfrentar o forte exército espanhol, tinha que enfrentar também uma parcela de seu próprio povo que estava colaborando com os conquistadores.

A ocupação espacial do território incaico seguiu a lógica sistêmica mercantilista, na qual o acumulo de metais preciosos era condição fundamental.

Para DUSSEL (2005, p. 61),

"Nunca houve empiricamente História Mundial até 1492 (como data da decolagem do "Sistema-mundo"). Anteriormente a essa data os impérios ou sistemas culturais coexistiam entre si. Somente com a expansão portuguesa a partir do século $X V$, chegada ao Extremo Oriente no século XVI, e com o descobrimento da América hispânica, todo o planeta torna-se o 'lugar' de 'uma só' história mundial."

Nesse sentido, não conseguiremos entender o avanço do modo de produção capitalista sem entender os processos de colonização, como apontou MORAES (2000, p. 23) em sua análise sobre a formação dos territórios coloniais:

"A colonização americana inicia-se com a instalação de enclaves, que atuam como bases de difusão do processo. Estes evoluem para regiões quando passam a abarcar espaços mais dilatados, que abrigam assentamentos e fluxos permanentes e consolidados. Tais conjuntos regionais, em suas articulações e complexizações, acabam por conformar efetivos territórios na América colonial, que apresentam uma divisão interna do trabalho com zonas de produção especializadas. Tais organizações espaciais, dotadas de instalações e assentamentos (e de fundos territoriais), com sua lógica de disposição das atividades e equipamentos no espaço, emerge como um dos elementos significativos da "herança colonial" das formações periféricas.

Enfim, os territórios coloniais atuaram como as bases da construção dos territórios nacionais na América Latina. Por isso, entender a dinâmica que presidiu suas formações, e conhecer os arranjos sociais gerados em cada 
caso, aparecem como pressuposto para a explicação da história das sociedades latinoamericanas."

A partir da lógica de análise da constituição da economia-mundo, pensamos que para uma melhor compreensão do objeto de estudo é fundamental fazer um breve levantamento histórico da Bolívia, desde a ocupação desse espaço pelos espanhóis.

O Estado Nacional conhecido como Bolívia originou-se do espaço colonial dominado pela Espanha, do século XVI ao XIX. Como assinala Fernando NOVAIS (2000), a colonização moderna representou a europeização das Américas e de outras áreas do planeta como resultado do expansionismo marítimomercantil, bem como a criação de espaços complementares ao processo de acumulação de capitais das áreas metropolitanas da nascente economia-mundo.

O poder metropolitano espanhol impôs suas determinações sobre a América Latina, por meio da sujeição manu militari dos povos e culturas indígenas estabelecidos no altiplano andino e na planície. Houve a destruição do Império Inca, contudo, certas estruturas indígenas relacionadas ao trabalho compulsório e a subordinação ao poder central foram mantidas devido a sua utilidade para a constituição de uma economia colonial baseada em enclaves mineiro-exportadores.

A partir destes enclaves desenvolveramse regiões e um território colonial, segundo GUMUCIO (1996, p. 14-15):

\footnotetext{
"Es en el altiplano y los valles interandinos donde hoy vive la mayor parte de la población, y es allí donde se formaron las altas culturas precolombinas de los quechuas y aimaras $y$ se asentaron las principales ciudades, como Chacras (hoy Sucre), La Paz, Cochabamba, Oruro y Potosi, y las explotaciones mineras. Em el oriente se fundaron las ciudades de Santa Cruz, Trinidad, Riberalta y Cobija, y uma miríada de pueblos fundados por los jesuítas em los siglos XVI y XVII."
}

MORAES (2000, p. 203) enfatiza a enorme importância da exploração da prata na organização do padrão da ocupação espacial da colônia e principalmente da importância fulcral de Potosí no processo de ocupação territorial por parte da Espanha

"... a ocupação segue um eixo que vai das minas de mercúrio de Huancavelica, trezentos quilômetros ao norte de Lima, passando por esta cidade, e avançando num sentido sul para a velha região mineira de Cusco, até atingir o cerro de Potosí (a cerca de 2000 quilometros de Lima), a montanha de prata descoberta em 1545, a quatro mil metros de altitude. Tal rota latitudinal firma-se com a introdução da técnica do amálgama na extração mineira, em 1572, a qual torna Huancavelica 'condição de Potosí' ".

Potosí, um local ermo, de difícil acesso, situado a cerca de 4000 metros acima do nível do mar e encravada no alto da Cordilheira dos Andes pode ser considerada, segundo Pierre VILAR (1981) um dos "lugares históricos do capitalismo", devido a enorme quantidade de prata ali encontrada. Em pouco tempo, a população cresce abruptamente e para abastecêla, tudo vinha de fora, nada era ali produzido, nada deveria tirar a atenção do que mais importava em Potosí: a retirada da prata.

A cidade de Cochabamba, fundada em 1571, e em menor grau as cidades de Tomina, fundada em 1575 e Tarija, fundada em 1574, encarregaram-se de abastecer com gêneros alimentícios a população do altiplano, principalmente trigo e milho. La Paz (Ciudad de Nuestra Señora de La Paz), fundada em 1548, especializou-se no cultivo de raízes de coca e na criação de animais, e prosperou graças à condição de ponto de parada no caminho entre as minas de Potosí e o litoral, e também por estar na rota entre Lima e Buenos Aires, enquanto Santa Cruz de la Sierra abastecia a mesma região com produtos tropicais. O trigo era trazido do Chile e os animais, tanto de carga quanto para o abastecimento de carne procediam da planície platina. Potosí se torna o pólo aglutinador de uma economia agrária periférica, que se estende por uma enorme área, constituída apenas para 
abastecê-la, pois na lógica sistêmica do Antigo Sistema Colonial, o lucro oriundo do processo de mineração compensa tais investimentos.

No que tange ao escoamento das mercadorias e ao recebimento dos produtos necessários à manutenção das condições básicas de vida na área mineira, MORAES (2005, p. 68) nos mostra que

"A ocupação do território colonial estrutura-se num padrão voltado para fora, isto é, a apropriação dos espaços obedece a um itinerário que exprime o sentido prioritário dos fluxos (centrípetos do ponto de vista da colônia, e centrífugos na ótica da metrópole). O desenho espacial básico observado é o denominado 'bacia de drenagem', em que um eixo de circulação central ramifica-se por caminhos que vão buscar as zonas de produção, e esse eixo tem por destino um porto (lacustre, marinho ou estuarino) que articula os lugares drenados com os fluxos do comércio ultramarino... Quanto mais ampla a área de drenagem e quanto mais intenso o fluxo praticado, maior será a importância do porto de referência na hierarquização dos lugares coloniais no interior de cada império".

A exportação dos minerais extraídos nesta área colonial, segundo MORAES (2000) em sua maior parte saia de Potosí e era enviada para Lima, de onde seguia para o porto de Callao, seguindo para o Panamá e de lá, enviada para Havana, de onde seguia para Sevilha, na Espanha. Tal trajeto, de acordo com Moraes, durava cerca de dezoito meses.

Vale ressaltar ainda que, por intermédio do porto de Buenos Aires, escoava grande parte da prata contrabandeada de Potosí, aliás, esse comércio clandestino de prata foi responsável pela segunda fundação da cidade de Buenos Aires, em 1580. Esta cidade tornar-se-á uma das principais rotas de abastecimento de Potosí, criando uma ligação entre a região mineira e o oceano Atlântico. Tal circuito foi legalizado em 1595 pela coroa espanhola. Não é a toa que, na primeira metade do século XVII, os portugueses pretendiam segundo BANDEIRA (1985), tomar posse de Buenos Aires, pois, além de permitir o controle da Bacia do Prata, abriria caminho para as minas de Potosí. Porém tal pretensão não se concretizou.

O declínio econômico de Potosí, quando a produção de prata entrou numa espiral descendente, ocorreu depois da segunda metade do século XVII. A cidade, que chegou a ter uma população fixa, no início do século XVII de aproximadamente $160 \mathrm{mil}$ pessoas, viu esse número cair para não mais que 30 mil habitantes. $\mathrm{Na}$ época da independência boliviana, em 1825, apenas 9 mil pessoas viviam em Potosí.

Outro processo distinto de ocupação do altiplano se deu pelo chamado "Piemonte" andino. A cidade de Assunção foi fundada em 1537 e serviu tanto como ponto de partida para expedições como de centro abastecedor de mate para Potosí. A partir de Assunção, os espanhóis rumando em sentido noroeste fundam, em 1561 a cidade de Santa Cruz de la Sierra, que começa a fornecer produtos tropicais à zona mineradora.

Esses dois processos distintos de ocupação, sendo o primeiro a partir do atual Peru e o segundo a partir do atual Paraguai, criando novos assentamentos populacionais em áreas de difíceis condições de vida nos mostra o grandioso circuito armado pela metrópole para garantir a extração, circulação e exportação da prata, envolvendo um arco maior de espacialização, que reunia as áreas andina e platina num território constituído pelo poder das relações sociais referentes ao Antigo Sistema Colonial, "... numa lógica na qual cada colônia aparece como parte de uma estrutura que trabalha para o centro do sistema" (MORAES, 2005, p. 64) sendo que, nesse processo, "as colônias são porções da economiamundo, na qual se apresentam como partes subordinadas de um império, e, em conjunto, delimitam a verdadeira periferia do mundo capitalista". (MORAES, 2005, p. 56).

Os portugueses, segundo BANDEIRA (1985), ficaram frustrados ao descobrir que nas terras destinadas pelo Tratado de Tordesilhas não encontraram um mísero grama de prata. Para tal intento, os bandeirantes começaram a 
embrenhar-se pelo interior do continente para encontrar o Eldorado ou mesmo alcançar Potosí. Nesse sentido, MORAES (2000) relata a expedição do bandeirante Raposo Tavares ocorrida entre 1648 e 1651 e que chegou até o sopé da Cordilheira dos Andes, passando posteriormente por Santa Cruz de la Sierra e fazendo uma descoberta importante. No relato de MORAES (2000, p. 395),

\begin{abstract}
"Partindo de São Paulo, sua expedição atingiu o sopé andino, transitando nas imediações de Santa Cruz de la Sierra, em seguida atravessando o interflúvio dos Parecis, penetrou na região amazônica, atingindo Belém, pela rota dos rios Mamoré, Madeira e Amazonas. Tal itinerário deu ciência da proximidade (e da não comunicação) das duas grandes bacias hidrográficas sul-americanas, pondo por terra o mito cartográfico da ilha Brasil".
\end{abstract}

A particularização do Antigo Sistema Colonial nas condições específicas do altiplano engendra um modo de sociabilidade marcado pela imposição da visão de mundo eurocêntrica e a consequente subalternização das populações indígenas, relegadas à mera condição de mãode-obra necessária à viabilização da economia colonial. MORAES (2000) destaca que a mineração implicou construções, assentamento, redes de abastecimento, perenização de fluxos, além de melhor organização da estrutura administrativa, ou seja, a incorporação exploratória do novo espaço, das terras e pessoas, à dinâmica da economia metropolitana. Nesta perspectiva, as hierarquias socioculturais tornam-se extremamente rígidas, expressando o caráter colonial desta sociedade, na qual o branco/europeu associa-se às várias nuances do colonizador e/ou agente metropolitano e o indígena ao fardo laboral nas atividades mineradoras. Cabendo aos mestiços transitar nos interstícios desta hierarquia social, simultaneamente, estrutura de produção. Como aponta Aníbal QUIJANO:"Na América, a ideia de raça foi um modo de outorgar legitimidade às relações de dominação impostas pela conquista (2005, p. 228)."

Portanto, não havia uma comunidade possível - real ou imaginada - nas condições vigentes de inferiorização da massa de população indígena e mestiça. Sendo que as elites que se constituíam a partir das relações econômicas coloniais não se preocupavam em criar elementos de consentimento e/ou persuasão para se associar ao caráter coercitivo do exercício do seu poder. "Os espanhóis, além de ocupar a paisagem física, também se apropriaram da paisagem espititual e cultural" (THIESSEN-REILY, 2008, p. 360). O exercício do poder, segundo os moldes da hegemonia gramsciana, pressupõe a integração mínima do povo ao sistema vigente, contrariando a situação concreta de visão e ação instrumental do povo, visto apenas como força de trabalho por parte da elite europeizante. A grande população indígena, a maior parte analfabeta no idioma metropolitano, permaneceu fora do processo de construção nacional das elites.

Contudo, enquanto contradição do próprio processo de particularização do Antigo Sistema Colonial ocorreu a preservação das comunidades indígenas. Comunidades estas que foram recontextualizadas, enquanto elemento de apoio sistêmico, já que faziam a gestão (controle e reprodução) da mão-de-obra. Instituições tradicionais como a mita (trabalho gratuito e compulsório nas minas) e a pongaje (o trabalho índio empregado para o serviço pessoal) foram apropriados pelos espanhóis e pela elite criolla, em função da enorme necessidade de mão-de-obra para a mineração. $\mathrm{Na}$ leitura de URQUIDI (2007, p. 74) "as comunidades indígenas permaneceram como residindo num país diferente, ocupando o mesmo território com as oligarquias, mas de modo subterrâneo".

Se por um lado estas comunidades representavam a submissão à ordem colonial, também se constituíram em pólos de aglutinação da população indígena e de sua cultura. Esta ambiguidade gerou movimentos de resistência nas áreas do vice-reinado do Peru, nos fins do século XVIII como as revoltas de Tupac Amaru e Tupac Katari (em 1778, sob sua liderança, indígenas cercaram a cidade de La Paz, porém logo foram contidos pelas forças espanholas). (GERAB e RESENDE, 1987, p. 21-28). 
Esses movimentos de rebeldia das populações coloniais foram debelados a ferro e fogo pelo consórcio formado pela elite colonial e as autoridades metropolitanas. A Era das Revoluções - a crise do Antigo Regime e do Antigo Sistema Colonial - na América hispânica não assistiu à constituição de Nações e nacionalismos, no sentido proposto por Eric Hobsbawm em seu livro "Nações e Nacionalismos desde 1780", de 2004.

A tônica das Luzes na América espanhola foi o protesto anticolonial, que galvanizou as elites no sentido de romper com a metrópole e se apropriar do poder colonial, como fundamento para a construção do seu Estado.

MARIÁTEGUI (2008, p. 36) indica que:

"As idéias da revolução francesa e da constituição estadunidense encontraram um clima favorável para sua difusão na América do Sul, porque na América do Sul já existia, ainda que embrionariamente, uma burguesia que, diante de suas necessidades e interesses econômicos, podia e devia ser contagiada pelo humor revolucionário da burguesia européia."

Os movimentos de independência na América Latina não foram comandados pela massa indígena. Os líderes foram os chamados "Crioulos" (descendentes de espanhóis nascidos na América) que não pensavam em criar uma sociedade indígena e igualitária. Suas pretensões eram apenas de se apossar das riquezas do território, ora apropriadas pelos espanhóis. Mas como tomar o poder sem perder o controle da grande massa indígena? A saída encontrada foi a adoção do nativismo que, segundo CHASTEEN (20018, p. 88,89),

"glorificava a idéia de uma identidade americana definida pelo local de nascimento, algo que os crioulos compartilhavam com os povos indígenas, com aqueles de sangue misto, mesmo com os filhos de escravos africanos. Com os apelos nativistas, os crioulos poderiam conquistar a independência mantendo a hierarquia social mais ou menos intacta... A maioria dos crioulos conservou as velhas noções da supremacia branca, como nos recém-independentes Estados Unidos"
Portanto, os processos de independência na Iberoamérica, nas palavras de CHASTEEN (2001, p. 93) "não cancelou o colonialismo nas nações latino-americanas. Pelo contrário, tornou-as pós-coloniais: agora se autogovernando, mas ainda moldadas pela herança colonial."

De acordo com Roberto CHOQUE (2006, p. 136), o processo de independência na Bolívia, comandado pela elite criolla, tratou primeiro de assegurar a independência da Espanha para, num segundo momento, se preocupar com os índios, a maioria da população. Em suas palavras:

"... A independência criolla do Estado ou da coroa da Espanha não significou sua libertação (dos indígenas) do sistema de exploração colonial, ou seja, com o novo Estado Republicano continuaram todas as suas cargas tributárias e serviços pessoais. Em outra ordem de coisas, o novo Estado marginalizou o indígena da sociedade civil."

Cabe ressaltar que os processos de independência na América Latina tiveram a participação inequívoca da Inglaterra, berço do capitalismo liberal, reconhecendo e financiando as repúblicas nascentes que imediatamente passaram a desempenhar seu papel na clássica Divisão Internacional do Trabalho, como fornecedores de produtos primários e receptores de produtos manufaturados.

\section{O Surgimento do Estado Boliviano}

No início do século XIX, Napoleão Bonaparte invade a Espanha e controla o poder. Tal fato abriu a possibilidade das elites crioulas de assumir definitivamente o poder. O Alto Peru (Charcas) foi palco do primeiro movimento independentista da América espanhola. Conforme KLEIN (2004, p. 61) em 1809 rebeldes liderados por Pedro Domingo Murillo instauraram uma Junta Tuitiva e proclamaram um regime independente em nome de Fernando VII (Rei da Espanha que abdicou em 1807). Tal movimento foi sufocado, com a morte de Murillo, em 1810. 
MERCADO (1988, p. 17) escreve que o nascimento da Bolívia como país independente é resultado de dois fatos: da crise do azougue (resultado do bloqueio inglês de Bonaparte) e da guerra das republiquetas (áreas rurais) entre 1809 e 1824. "Um Estado fraco e isolado do mundo... um Estado em guerra perpétua com sua própria população" (1988, p. 19).

A Bolívia nasce como um "Estado-tampão" entre a Argentina e o Peru (Figura 3) pois a elite da cidade de Lima tinha na construção do Estado boliviano um anteparo para a agressividade argentina. Por isso, Simon Bolívar não conseguiu levar a cabo suas pretensões de construir uma só América, além do mais, segundo Klein, a Argentina tinha uma posição hostil à ideia e o próprio Bolívar temia um Estado peruano com muito poder.

A independência boliviana se concretizou em 6 de agosto de 1825, sob a liderança do general Antonio José de Sucre. Uma república eminentemente indígena: "A nova república tinha uma população estimada de 200.000 brancos, 100.000 cholos e aproximadamente 800.000 camponeses índios." (KLEIN, 2004, p. 73)

Sucre, o primeiro presidente da jovem república abandona o poder em 1829, sendo substituído pelo Marechal Andrés de Santa Cruz.

Para se compreender a construção da identidade nacional boliviana é necessário entender as raízes e as consequências das guerras travadas pela Bolívia. Segundo WASSERMAN (2004, p. 320):

"As classes dominantes usaram as derrotas como pretexto para justificar a idéia de que a heterogeneidade étnica do país constituía-se em uma 'fraqueza originária', um 'defeito congênito', que impedia a Bolívia de ganhar uma guerra contra vizinhos poderosos e que, ao mesmo tempo, constituir-se-ia em um obstáculo para se atingir a modernidade".

\section{Boliviana \\ A Guerra da Confederação Peruano-}

A primeira derrota boliviana deu-se na Costa do Pacífico, na chamada Guerra da
Confederação Peruano-Boliviana (1836-1839), quando Peru e Bolívia se unificaram sob o domínio de Andrés de Santa Cruz, constituída por decreto em 28 de outubro de 1836 . O Chile não aceitou a tentativa de unificação, declarou guerra à nascente Confederação em dezembro de 1836. Segundo SANTOS (2002, p. 51):

"O Peru constituía-se, desde o período colonial, no principal mercado para a produção de trigo e farinhas chilenas. Nesse momento, o Chile, que já havia conseguido superar a fase de tensões centrífugas internas com o início da chamada fase dos 'Governos dos Decênios', lançava-se no projeto de transformar Valparaíso no principal porto do Pacífico Sul, ponto de parada obrigatório dos navios que dobravam o Cabo de Hornos com destino ao Oriente. A hegemonia de Valparaíso sobre Callao foi decidida na guerra que o Chile sustentou contra a Confederação Bolívia-Peru, que teve como causa imediata a denúncia do tratado que concedia preferências comerciais mútuas e a recusa das autoridades da confederação a derrogar a legislação que aumentava os direitos peruanos sobre as mercadorias que chegassem ao seu mercado com escala em Valparaíso. Porém o motivo primordial do conflito bélico foi dirimir a supremacia comercial do Pacífico Sul entre Valparaíso e Callao."

Ao término da guerra, em janeiro de 1839, com a vitória chilena na batalha Yungay, a Confederação foi encerrada, mantendo a hegemonia do Pacífico Sul nas mãos do Chile.

Para MERCADO (1988, p. 20), a intenção de Andrés, apesar do projeto conservador, pretendia "dar um projeto nacional a um país que não o tinha. Há nisto a tentativa de aplicação do centralismo de províncias, que tinham deixado de ser centrais".

\section{A Guerra do Pacífico}

A segunda disputa internacional da Bolívia aconteceu com o Chile na chamada "Guerra do Pacífico" (1879-1884). 
Figura 3: Mapa do território original da República da Bolívia, na data de sua fundação, 06/08/1825

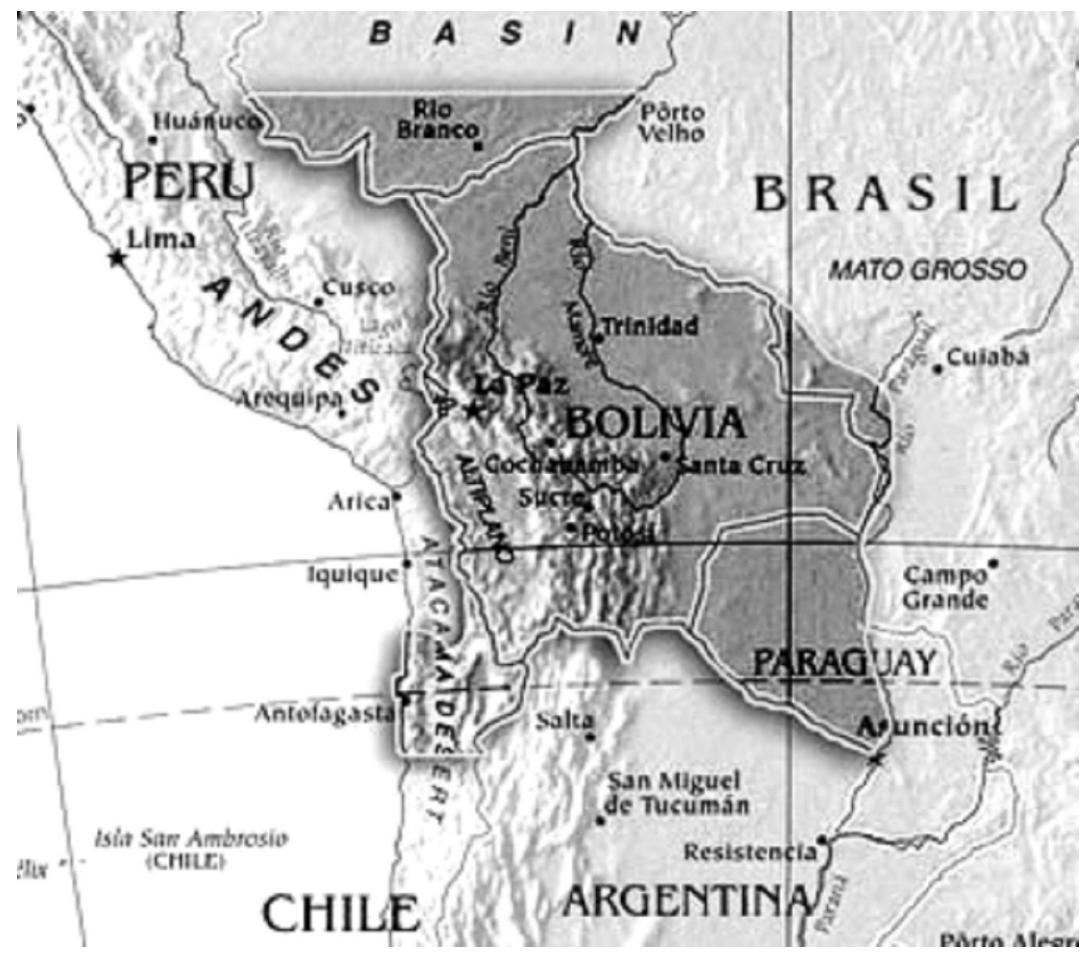

Fonte: www.turismobolivia.bo/map-nacimiento.jp. Acessado em 24/12/2008

Essa guerra é oriunda de um conflito originado em 1842, em função da descoberta da aplicabilidade agrícola do nitrato de sódio (salitre) e do guano (adubo rico em nitrogênio, proveniente das fezes de aves migratórias) no deserto de Atacama, que até então, junto ao Pântano de Tamarugal, eram áreas repulsivas, apresentando limites imprecisos entre o Peru, o Chile e a Bolívia.

A corrente marítima fria de Humboldt ocasiona o fenômeno da Ressurgência. Essa corrente marítima se desloca no sentido norte, em uma linha paralela ao litoral. Na costa peruana, as águas superficiais se aquecem e sofrem um deslocamento, devido à ação dos ventos locais, afastando-se do litoral. A massa de água fria que se encontrava nas profundezas aflora, trazendo consigo nutrientes (plânctons) que estavam no fundo do mar, aumentando consideravelmente a quantidade de peixes nesse litoral.

Alimentadas pelos cardumes, as gaivotas e as alcatrazes excretaram durante milhares de anos muitas toneladas de matérias fecais ricas em nitrogênio, fosfatos e amoníaco que agora serviriam para enriquecer o empobrecido solo europeu, e engordar as contas bancárias da burguesia britânica e alemã. O salitre foi encontrado em grandes quantidades na província de Tarapacá, no Peru, e na província de Antofagasta.

Capitais de empresas chilenas passaram a controlar a extração desses produtos e a 
Inglaterra transformou-se no principal comprador e no pós-guerra começou a controlar o comércio e as estradas de ferro construídas para esse fim. Segundo SANTOS (2002), baseado na análise documental de Victor Kiernan e de Héctor Bruit, a Guerra do Pacífico não foi fruto do imperialismo inglês, mas foi gerada por interesses locais da burguesia chilena e que, apenas no final da guerra, o capital inglês predominou, não como objetivo, e sim como resultado.

De acordo com SANTOS (2002, p. 32), havia um acordo estabelecido entre Bolívia e Chile, no ano de 1874 , que protegia o capital chileno de novos impostos por um período de 25 anos. Em 1878 o governo boliviano decidiu aumentar os impostos em 10 centavos sobre cada 100 quilos de salitre pagos pelas salitreiras estrangeiras. Além da ameaça de encampar os bens da Companhia Anônima de Salitre e a Ferrovia de Antofagasta, o Chile reagiu enviando seus exércitos para as províncias de Tarapacá e Antofagasta.

A venda das concessões de exploração da área e a entrega do guano e do salitre a John Thomas North, proprietário da Liverpool Nitrate Company (MERCADO, 1988, p. 20) levaram o Chile, contando com o apoio inglês, a atacar o Peru e a Bolívia, tomando desses países esse árido território que além de conter diversas riquezas minerais era a porta de saída da Bolívia para o Oceano Pacífico, deixando claro que os interesses econômicos impõem uma definição clara dos limites.

Segundo SANTOS (2002, p. 143), a guerra do Pacífico encerrou-se com a assinatura do Tratado de Ancón, em 20 de outubro de 1883, e a "trégua com a Bolívia só foi firmada em 4 de abril de 1884. Os dois instrumentos, entretanto, consagraram a vitória chilena, com a cessão do litoral boliviano e das ricas províncias de Antofagasta e Tarapacá ao Chile."

Ao final desse segundo conflito, os chilenos mais uma vez são reconhecidos como a força militar dominante no Pacífico Sul da América (SANTOS, 2002), tendo os impérios britânico e brasileiro como aliados.
Para o Chile, a importância de uma aliança com o Brasil residia na possibilidade de o Brasil conter uma possível aliança da Argentina com o Peru e a Bolívia, o que seria desastroso para as pretensões chilenas.

Até hoje a Bolívia se ressente dos 120.000 $\mathrm{km}^{2}$ perdidos para o Chile nessa guerra e ainda guarda, no Lago Titicaca, sua pequena frota da Marinha de Guerra, esperando para que um dia seu território, perdido na Guerra do Pacífico, seja devolvido (Figura 4).

No que tange à saída boliviana para o Pacífico, foi firmado entre os governos chileno e boliviano um acordo, em 1904, de cessão do litoral marítimo "a cambio de 300.000 libras esterlinas y de la construcción del ferrocarril Arica-La Paz por parte del vecino país" (GUMUCIO, 1996, p. 20).

Segundo a análise de WASSERMAN (2004, p. 340), a

"ausência de uma saída soberana para o mar ou a falta do 'litoral' deixou a Bolívia em segundo plano da DIT (Divisão Internacional do Trabalho) ou duplamente dependente; por um lado, os centros hegemônicos do capitalismo e, por outro lado, os países vizinhos que pudessem prover a comercialização dos seus produtos por via marítima. Com isso, o país empobreceu muito e manteve um padrão de desenvolvimento baixo em relação aos demais países da região."

Vale ressaltar que esse conflito serviu para uma nova tentativa de construir uma Federação entre Bolívia e Peru, ocorrida em 1880. Conforme SANTOS (2002, p. 139)

"O desalento atingiu os aliados e, talvez como forma de superá-lo, em junho de 1880, os plenipotenciários Pedro José Calderón, do Peru, e Melchor Terrazas, da Bolívia, reuniram-se com o objetivo de estabelecer uma federação entre os dois países. $O$ ministro brasileiro em La Paz, em resposta a sua consulta sobre a posição do império frente a tal hipótese, foi informado que 'o Brasil não tem interesse em contrariar a execução do plano, aí concebido, de uma confederação entre a Bolívia e o Peru' 
Figura 4: Território perdido para o Chile, na Guerra do Pacífico

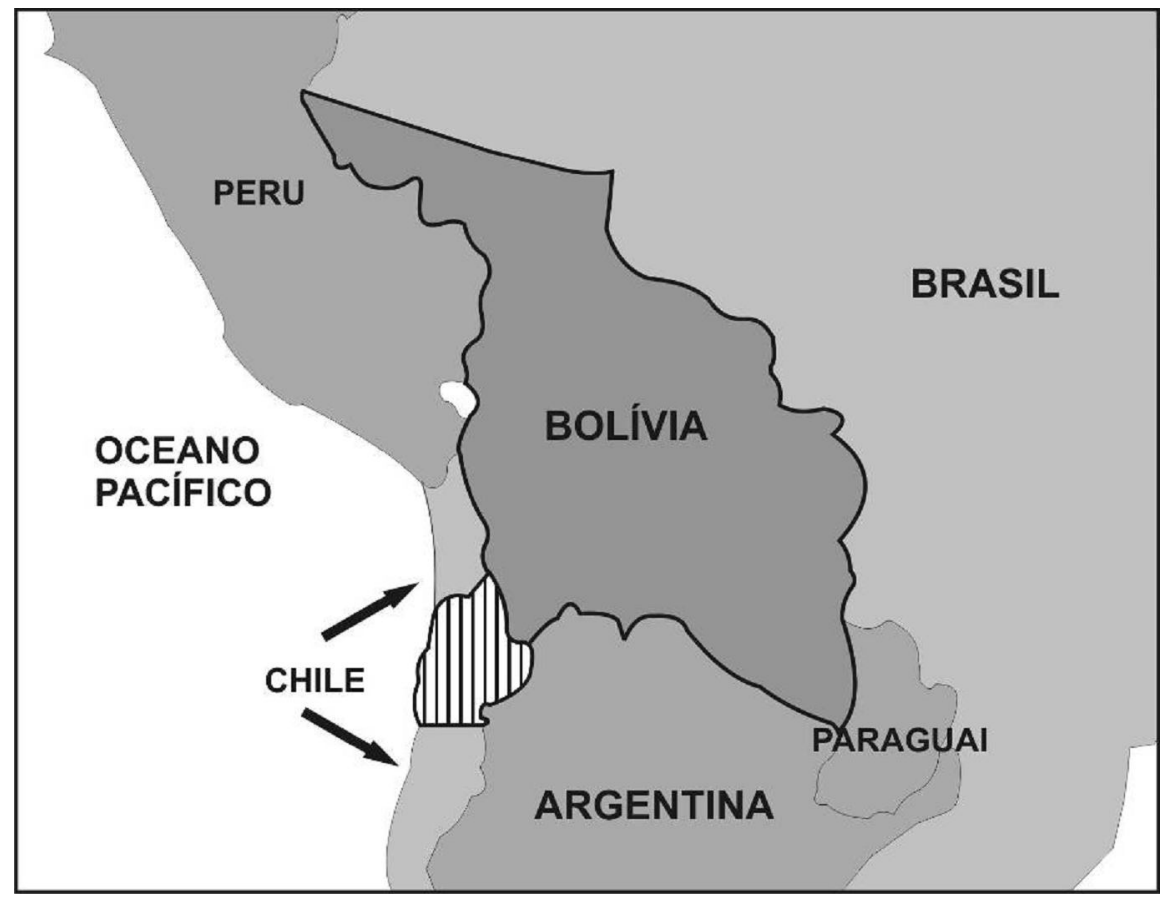

Fonte: FREIRE. E. M., 2008, a partir de MESA, J. GISBERT, T. GISBERT, C. História de Bolívia. La Paz: Ed. Gisbert, 2003.

e instruído a 'limitar-se a informar o governo imperial do que for ocorrendo'. A idéia dessa confederação, no entanto, não prosperou."

\section{A Questão do Acre}

Em 1900 eclodiu a rebelião no Acre, que se prolongou por três anos e, ante a ameaça de uma intervenção direta do governo brasileiro, foi firmado entre Bolívia e Brasil o Tratado de Petrópolis (1903), no qual a Bolívia cederia o território do Acre ao Brasil em troca de dois milhões de libras esterlinas e o governo brasileiro se comprometeria a construir a estrada de ferro Madeira-Mamoré, para superar o trecho encachoeirado do rio Madeira, possibilitando o acesso das mercadorias bolivianas aos portos brasileiros do Atlântico (inicialmente Belém do Pará, na foz do rio Amazonas).
Tal conflito tem sua origem ligada à mundialização do capitalismo fundamentada na Segunda Revolução Industrial, que passou, a partir da segunda metade do século XIX, a utilizar de maneira crescente a borracha, seja para a produção de pneus seja na fabricação de correias para máquinas e outros artefatos industriais. 0 látex, matéria-prima da borracha, naquela época, apenas era encontrado na parte sudoeste da floresta equatorial amazônica, dividida entre a República da Bolívia e o Império brasileiro.

Até o final do século XIX, a fronteira entre Brasil e Bolívia foi alvo de constantes embates entre os dois países. Segundo SANTOS (2002, p. 103), vários insucessos marcaram a tônica das negociações bilaterais como a missão de Duarte da Ponte Ribeiro (1851-1852) e a tentativa de João da Costa Rego Monteiro em 1860. Esse problema só seria resolvido com o Tratado de 
Amizade, Limites, Navegação, Comércio e Extradição, assinado no dia 27 de março de 1867. Mesmo favorecendo a Bolívia e sofrendo duras críticas no Brasil, nas palavras de Duarte da Ponte Ribeiro, pois contrariava o princípio do uti possidetis, defendido pelo Brasil, estava acertada a fronteira entre os dois países.

Novos conflitos vieram a acontecer na última década do século XIX em função de problemas na demarcação dos marcos fronteiriços entre os dois países, principalmente no que tange à definição dos limites entre os rios Madeira e Javari.

Neste ínterim milhares de brasileiros, vindos principalmente do nordeste, já ocupavam uma extensa área de terras até então pertencentes à Bolívia, atrás de trabalho nos seringais do local.

De acordo com SENA (2002, p. 6), a questão dos marcos fronteiriços só se resolveria em 23 de setembro de 1898, depois de três anos de negociações, quando o Brasil reconhecia que o território de Aquiri seria definido pela Linha Cunha Gomes, considerando-o boliviano.

Aproveitando o acordo, o ministro boliviano José Paravicini fundou o povoado de Puerto Alonso, além de legislar sobre a navegação dos rios da região, estabelecendo taxas aduaneiras e impostos de comercialização.

Tais atitudes do representante boliviano não foram aceitas pelos cerca de 60 mil brasileiros residentes no Acre e, em 14 de julho de 1899, o espanhol Luiz Galvez Rodriguez de Arias, a soldo do presidente da Província do Amazonas, Coronel Ramalho Júnior, declara o Estado Independente do Acre, solicitando sua anexação ao Brasil, porém, tal proposta foi recusada pelo governo brasileiro. Tal aventura durou até 9 de março de 1900 , quando uma coluna militar organizada pelo governo brasileiro terminou com Estado recémfundado e devolveu-o para a Bolívia.

Batalhas foram travadas entre exércitos particulares organizados pelos "barões da borracha" e o exército boliviano, porém, sem intervenção do exército brasileiro.
Para ocupar a área, o governo boliviano fechou um acordo, em dezembro de 1901, com a empresa The Bolivian Syndicate of New York City in North America, cujo presidente indicado era o filho de Theodore Roosevelt, o novo ocupante da Casa Branca.

Nas palavras de DORATIOTO (1994, p. 77):

"uma empresa estrangeira, o Bolivian Syndicate. O Sindicato, como essa empresa ficou conhecida, era formado por firmas inglesas e norte-americanas. Ele recebeu autorização de La Paz para explorar e administrar o território acreano, podendo nele arrecadar impostos, organizar polícia, manter tropas e barcos de guerra. Enfim, a Bolívia praticamente transferia sua soberania (no Acre) para uma empresa privada".

Em 1902, em função das medidas draconianas impostas pelo governo boliviano, eclode uma nova rebelião de brasileiros, comandada pelo ex-militar José Plácido de Castro e com o apoio do presidente do Amazonas. De acordo com SENA (2002, p.13), o grupo de cerca de oitocentos homens comandados por Plácido de Castro expulsou tropas bolivianas estacionadas no Acre, expulsou da área a diretoria do Bolivian Syndicate para Belém, no Pará, e decretou a segunda independência do Acre.

Para reprimir os sublevados, o presidente da Bolívia, general José Manuel Pando prepara pessoalmente uma pequena tropa para marchar contra os brasileiros.

Nesse contexto de crise, assume o Ministério das Relações Exteriores do Brasil o monarquista José Maria da Silva Paranhos Filho, o Barão de Rio Branco que

"Inverteu a política seguida pelo Brasil, de reconhecer como indiscutível a soberania boliviana sobre o Acre. Rio Branco declarou o território zona litigiosa, lembrando o artigo XIV do acordo de limites de 1867, o qual afirmava que 'se no ato da demarcação ocorrerem dúvidas graves, provenientes de inexatidão do presente tratado, serão estas dúvidas decididas amigavelmente por ambos os governos'. Rio 
Branco passou, então a reclamar da Bolívia o território ao norte do paralelo 10 graus 20 minutos." (DORATIOTO, 1994, p. 78).

Em fevereiro de 1903, o presidente brasileiro Rodrigues Alves deu permissão para o deslocamento de tropas brasileiras para a área em litígio. Nesse cenário, o Barão de Rio Branco parte para as negociações com o governo boliviano. Rio Branco tratou de cuidar para que o Bolivian Syndicate não tivesse participação nas negociações. Para tanto, o governo brasileiro pagou para essa empresa, segundo DORATIOTO (1994, p. 78) a importância de 110.000 libras esterlinas para renunciar a quaisquer pretensões no Acre, vale salientar que tal empresa não havia feito investimentos na área.

O acordo entre os dois países foi alcançado em 17 de novembro de 1903, na assinatura do Tratado de Petrópolis. Sobre o Tratado de Petrópolis, DORATIOTO (1994, p. 79) escreveu que

"por esse tratado o Acre, em um total de $191.000 \mathrm{~km}^{2}$, tornou-se brasileiro. À Bolívia coube, na região amazônica, um trecho de $2296 \mathrm{~km}^{2}$, situado entre os rios Abunã e Madeira, obtendo acesso, assim, ao oceano Atlântico, mediante a navegação do rio Amazonas e seus afluentes. O corredor amazônico, nas palavras de Bradford Burns, 'deu maior facilidade de manobra à Bolívia em suas relações com a Argentina e o Chile, ao mesmo tempo que a ligava ao Brasil ainda mais intimamente'. Na região platina foram transferidos à soberania boliviana $723 \mathrm{~km}^{2}$ sobre a margem direita do rio Paraguai, dando ao país outro acesso ao Atlântico, além de $194,7 \mathrm{~km}^{2}$ de outras pequenas parcelas de terra. Por não haver equivalência nas áreas transferidas, o Tratado de Petrópolis determinou que o Brasil pagasse dois milhões de libras esterlinas à Bolívia. Foi estabelecido também que o Brasil construiria entre os rios Madeira e Mamoré uma estrada de ferro que permitiria à Bolívia ter acesso ao oceano Atlântico através da região amazônica." (Figura 5).

Figura 5: Território perdido para o Brasil, na Guerra da Borracha

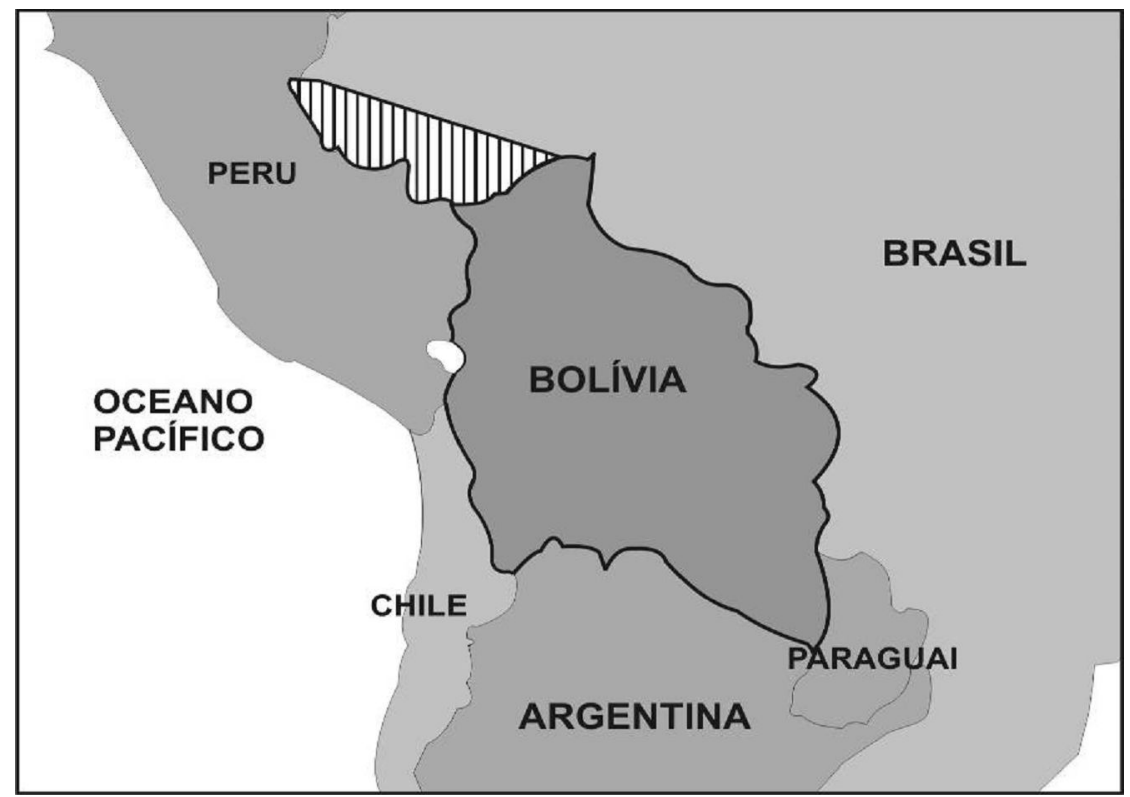

Fonte: FREIRE. E. M., 2008, a partir de MESA, J. ; GISBERT, T. e GISBERT, C. Historia de Bolívia. La Paz: Ed. Gisbert, 2003 
De acordo com dados extraídos do sítio do Museu Paulista

"O projeto de construção da ferrovia Madeira - Mamoré encerra um dos episódios mais significativos da história da ocupação da Amazônia e tentativa de integrá-la ao mercado mundial através da comercialização da borracha. A intenção do projeto era estabelecer a ligação entre as regiões produtoras de látex, nas proximidades dos rios Madeira, Mamoré, Guaporé e Beni (este último na Bolívia). As primeiras tentativas, datadas ainda da Segunda metade do século XIX, fracassaram ou por falta de verbas ou por falta de infra-estrutura possível, a partir de 1907, graças à experiência da companhia americana May, Jekyll \& Randolph, que já desfrutava de considerável Know-how na área, em virtude de projetos arregimentação maciça de mão-de-obra. Por esta razão, entre 1907 - 1912, período de construção da ferrovia, cerca de 30.000 trabalhadores de várias partes do mundo foram engajados, dos quais aproximadamente 6.000 faleceram no local. Ironicamente, a ferrovia Madeira-Mamoré entra em funcionamento no ano em que tem início a derrocada da produção de borracha nacional no mercado mundial. Mais tarde, a opção de Juscelino Kubitschek pelo investimento em rodovias como via de integração nacional se concretiza na região nortista com a inauguração da estrada ligando Cuiabá a Porto-Velho, em 1960. Teve início, então, a fase de sucateamento e abandono da ferrovia. Em 1972, ela foi totalmente desativada e seus arquivos incinerados. ${ }^{15}$

\section{A Guerra do Chaco}

Foi na Guerra do Chaco (Figura 6), triângulo formado pelos rios Paraguai, Pilcomayo e Parapetí, desenvolvida contra o Paraguai, entre os anos de 1932-1935, que a Bolívia conheceu

Figura 6: Território perdido para o Paraguai, na Guerra do Chaco

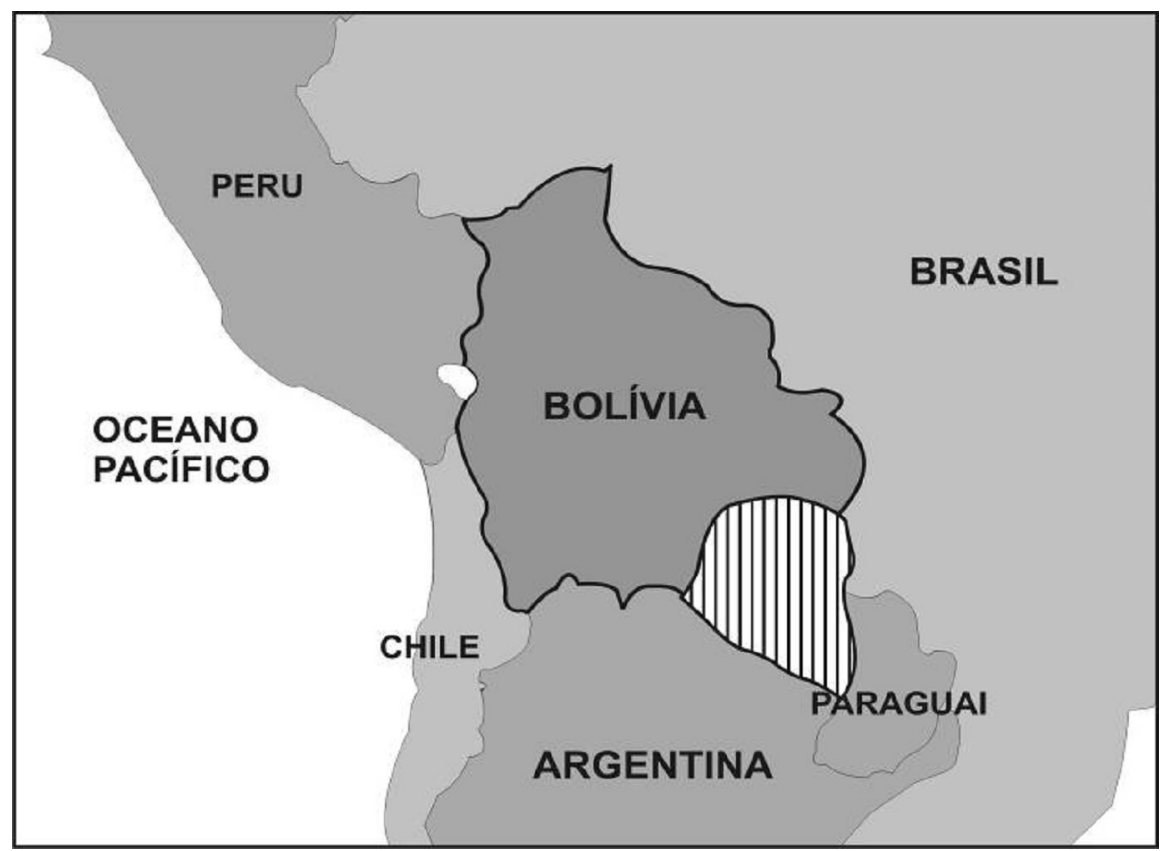

Fonte: FREIRE. E. M., 2008, a partir de MESA, J.; GISBERT, T. e GISBERT, C. Historia de Bolívia. La Paz: Ed. Gisbert, 2003. 
uma de suas piores derrotas internacionais. De acordo com ANDRADE (2007, p. 33), na disputa por essa inóspita área, o exército boliviano, treinado por ex-oficiais prussianos, perdeu mais de 50.000 soldados

Na análise de DORATIOTO (1994, p. 83), a necessidade da posse do território do Chaco torna-se fundamental para a Bolívia em função da perda do seu litoral para o Chile, na Guerra do Pacífico. A planície do Chaco permitiria acesso ao rio Paraguai e daí ao rio da Prata e, por conseguinte, ao Oceano Atlântico.

A tentativa de delimitação fronteiriça entre os dois países levou a pequenos confrontos entre os dois países, como em 1927, porém, mesmo com a mediação da Argentina, em 1928, Bolívia e Paraguai não chegaram a um acordo sobre as fronteiras. As relações diplomáticas entre os dois países foram rompidas em função de um ataque paraguaio a uma fortificação boliviana em dezembro de 1928. Os dois países aceitaram a mediação da Conferência Pan-Americana de Conciliação e Arbitragem que, segundo Doratioto, propôs a soberania do Paraguai no Chaco Boreal e concedia à Bolívia o porto da Baia Negra. Tal solução foi rejeitada por ambos os países.

A economia boliviana entrou em um forte processo de deterioração, impactada, principalmente pelos efeitos da crise econômica de 1929. De acordo com dados coletados em GUMUCIO (1996, p. 35), o principal produto de exportação da Bolívia naquele período era o estanho, cuja tonelada custava, em 1928, 225 libras. Em função da crise econômica do capitalismo, em 1932 o preço do estanho despencou para 118 libras. Nesse ano, o principal grupo mineiro boliviano (Grupo Patiño) reduziu seu quadro de funcionários de 7000 empregados para apenas 2000.

Em março de 1931 Daniel Salamanca, representante da oligarquia e do capital internacional, assume a presidência da Bolívia. Nas ruas, as greves e movimentos de estudantes aumentavam, exigindo melhoria das condições de vida. No dia 10 de julho de 1931, o presidente Daniel Salamanca voltou a romper relações diplomáticas com o Paraguai, depois de um pequeno desentendimento sobre a posse de uma laguna na fronteira entre os dois países.

ANDRADE (2007) enfatiza que em julho de 1932, quando a guerra se iniciou, o exército boliviano, formado principalmente por índios e mestiços pobres, começou a enfrentar grandes dificuldades. Os soldados bolivianos eram em sua maioria acostumados a viver nas terras frias e de pouco ar dos Altiplanos Andinos. Eles foram obrigados a lutar numa região inóspita, seca e arenosa. A resistência física mostrou ter um valor muito maior à capacidade militar, ao tamanho do exército ou ao seu treinamento. As regiões onde começaram os combates eram distantes das principais cidades bolivianas, não existiam estradas e era difícil chegar água e alimentos para os soldados.

E nessas condições, desde cedo os paraguaios superaram em capacidade militar o exército inimigo. Ao contrário dos bolivianos, os paraguaios, mesmo em número inferior, viviam e conheciam melhor a região e estavam mais próximos de suas cidades e de seus pontos de abastecimento. Assim, ficaram numa situação mais vantajosa que a dos bolivianos para a luta. O que o governo boliviano esperava que fosse uma rápida guerra de conquista, tornou-se um pesadelo. Milhares de soldados morreram de sede e de fome a centenas de quilômetros dos principais centros econômicos da Bolívia. A situação tornava-se cada vez mais desesperadora para as forças militares do altiplano. ANDRADE (2007, p. 32) salienta que:

"Em 25 de novembro de 1934 o presidente Daniel Salamanca foi deposto por oficiais do exército em pleno desenvolvimento das operações militares, quando tentava mais uma vez trocar a chefia do alto comando. O governo foi entregue ao vice-presidente Tejada Sorzano que tratou de imediatamente iniciar conversações e assinar a paz com o Paraguai em 14 de junho de 1935. A Bolívia terminava o conflito deixando mais de 65000 soldados mortos, pelo menos 240 mil quilômetros quadrados de território para o Paraguai e a economia nacional destroçada". 
Assim como na Guerra do Pacífico, entra em discussão se a Guerra do Chaco teve interesses imperialistas, haja vista que na área em disputa, foram descobertas algumas jazidas de petróleo e a posse dessas jazidas motivou o desencadeamento da guerra. Eram as disputas entre as empresas petrolíferas. Seguindo esta linha de raciocínio estão Omar Díaz Arce e Júlio José Chiavenato. Para esses autores, a Standard Oil of New Jersey (atual Exxon), representando o imperialismo estadunidense, insuflou a Bolívia e a Royal Dutch Shell, representando o imperialismo inglês, aliou-se à Argentina, que dominava o Paraguai. Ambos armaram e empurraram o Paraguai para a guerra. "Não se pode explorar o petróleo sem controlar os governos dos respectivos países onde se vai buscá-10" (CHIAVENATO, 1979, p. 106). De acordo com essa linha de raciocínio, a Standard Oil pretendia construir um gasoduto, que cortaria o território paraguaio, para a exportação de seu petróleo explorado em território boliviano, porém, o Paraguai negou-lhes a licença de construção do gasoduto, atendendo aos interesses da Royal Dutch Shell que, por sua vez, queria apoderar-se dos poços bolivianos.

Para corroborar com esta tese, CHIAVENATO (1979, p. 108) cita uma afirmação de Libório Justo, filho do então presidente Justo, da Argentina:

\begin{abstract}
"Na Bolívia, onde domina o capital norteamericano, a Standard Oil necessitava de uma saída para o rio Paraguai para seus poços de petróleo no leste daquele país. Por trás do Paraguai, a companhia inglesa Royal Dutch tratou de evitá-lo. Essa foi a causa do conflito que tem ensanguentado o continente".
\end{abstract}

\section{p. 108),}

Ainda segundo CHIAVENATO (1979,

\footnotetext{
"Aí está a raiz da guerra: os trustes petrolíferos jogam com argumentos e intrigas que envolvem cada uma das duas companhias, apresentando a rival como vilão da história. $A$ Royal Dutch Shell - de quem a Argentina é indisfarçável aliada e o Paraguai um passivo instrumento - fomenta as acusações pela
}

imprensa e nos meios diplomáticos, afirmando que a Standard Oil quer um oleoduto para exportação e, para conseguí-lo, está armando a Bolívia para uma guerra de conquista de territórios paraguaios no Chaco, por onde passaria esse oleoduto. A Standard Oil, da mesma forma, alimenta as intrigas de que a Royal Dutch Shell, aliada dos interesses argentinos, pretende tomar vastas regiões do Chaco, chegar ao sopé dos Andes e apossarse das áreas petrolíferas bolivianas, que passariam a pertencer à Argentina e seriam exploradas pela Shell".

Chiavenato cita o senador estadunidense Huey Pierce Long que, em maio 1934, denunciou ao congresso dos Estados Unidos da América que um empréstimo realizado à Bolívia em 1928, denominado Dillon Reed, no valor de 23 milhões de dólares, só se tornou possível graças ao aval da Standard Oil. A maior parte do dinheiro foi dirigida para a compra de material bélico, usado na guerra contra o Paraguai. Pouco tempo depois, em 10 de setembro de 1935, o senador Long foi assassinado a tiros em frente ao congresso em Washington.

Zavaleta Mercado, por outro lado, sustenta que, apesar da Argentina apoiar o Paraguai com alimentos, armas e munições e a Royal Dutch Shell ter bastante interesse na Argentina, os interesses comerciais eram bem maiores que desentendimentos fronteiriços, pois a Standard Oil, a partir de seus campos na Bolívia, exportava petróleo, via um oleoduto clandestino para a Argentina. Portanto, se a Standard Oil realmente tivesse interesse na vitória da Bolívia, minaria qualquer tentativa de compra de seus produtos por parte de um país que apoiava o inimigo Paraguai. Quando o governo boliviano descobre o oleoduto clandestino, determina a imediata nacionalização da Standard Oil.

GUMUCIO (1996, p. 48) também descarta a participação das companhias de petróleo na disputa pelo Chaco. Ele escreve que a Bolívia

"... no logró tampoco el único objetivo que habría paliado em cierta medida la carnicería: um puerto sobre el rio Paraguay para romper 
la angustiante asfixia de la mediterraneidad impuesta por Chile desde 1879".

A nacionalização da empresa é encarada por CHIAVENATO (1979) como uma represália, por parte do governo boliviano, pois a Standard Oil recusou-se a emprestar mais dinheiro para uma guerra, já em seus estertores, com um discurso de que as riquezas do país devem ficar em benefício da Bolívia e não de uma companhia estrangeira.

Ao término da Guerra do Chaco, grandes transformações ocorreram na Bolívia, segundo VIOTTI (2000, p. 188):

"No plano político, resultou na superação do sistema vigente desde 1880, com a crise tanto dos governos civis quanto dos partidos políticos tradicionais. No plano econômico, a Guerra do Chaco, associada aos efeitos da Grande Depressão, marcou o fim da expansão da indústria mineira, cuja produção e produtividade começaram a declinar. Com o início do declínio da mineração, passaram a adquirir maior importância as riquezas do Oriente boliviano, especialmente o petróleo.

Esta derrota não foi apenas militar, mas expressou também a crise do próprio Estado boliviano, na sua forma historicamente dada de imposição do metabolismo social, marcada pela exclusão política das camadas populares. A condução da guerra - marcada pelo desperdício de vidas humanas - expressou a velha lógica criolla de abusar das populações indígenas e mestiças. O morticínio apenas havia passado das minas para os canhões. Por outro lado, a Guerra do Chaco marcou o surgimento de uma consciência nacional.

As disputas anteriores, motivadas por novos espaços econômicos, foi alimentada por pequenos contingentes do exército boliviano. A guerra do Chaco foi verdadeiramente uma guerra nacional, que envolveu pessoas de todas as partes da Bolívia, principalmente indígenas e mestiços pobres. Vale destacar o que escreveu URQUIDI (2007, p. 76)

"O Chaco simboliza mais que a fragilidade de um projeto estatal. A derrota e a perda do território do Chaco desencadearam nas colunas do exército as bases contemporâneas do nacionalismo boliviano, uma vez que, no cenário da guerra e na centralização das ações pelo exército, juntaram-se pela primeira vez os setores dispersos da sociedade, que comportavam a essência da nação: a pequena burguesia urbana, os artesãos, os camponeses e os mineiros.

Diferentemente do que ocorreu na Guerra do Pacífico, quando a participação estatal e a convocação social boliviana foram escassas, para o Chaco acudiu gente de todos os cantos do país, que se reuniu e se reconheceu como pertencente a um mesmo território que precisava ser defendido.

Por isso, a guerra, mais do que a derrota do Estado oligárquico, significou o encontro das massas dispostas a construir um sentimento nacional a partir da única instituição centralizadora que era o exército."

Concretamente, a população passa a reivindicar uma participação maior no destino dessa sociedade, a qual o Estado da elite boliviana não se preocupou em se tornar Nacional, até mesmo para melhor exercer suas condições de hegemonia. Portanto, a perspectiva "nacional" (incluindo as lutas contra o capital e o resgate da cidadania da população indo-americana) passa a pertencer às lutas das massas populares, e esta experiência de luta passa a moldar o bloco histórico de camponeses e operários.

\section{Notas}

${ }^{1}$ www.ine.gov.bo (Acessado em 14 de outubro de 2008).

2 INE, VAI, UNFPA.- http://www.ine.gov.bo Acesso 1de novembro 2007)

${ }^{3} \mathrm{O}$ nome inca refere-se a império e não, em termos restritos, aos seus habitantes, segundo Charssten, 2001: 29.
4 www.ine.gov.bo (Acessado em 14 de outubro de 2008).

5 www.mp.usp.br/mamore (Acessado em 19 de outubro de 2008). 


\section{Bibliografia}

ANDRADE, E. O. A revolução boliviana. São Paulo: Ed. UNESP, 2007. 182 p.

ARCE, O. D. O Paraguai Contemporâneo (1925 1975). In CASANOVA, P. G. (org). América Latina: história de meio século. Vol. 1. Brasília: Editora Universidade de Brasília, 1988. 332 p.

BANDEIRA, L. A. M. O expansionismo brasileiro e a formação dos Estados na Bacia do Prata. Rio de Janeiro/Brasília: Ed. Revan/Ed. Universidade de Brasília, 1985. 254 p.

BARROS FILHO, O. Bolívia: vocação e destino. São Paulo: Versus, 1980. 208 p.

BARSOTTI, P. PERICÁS, L. B.(Org.) América Latina: história, idéias e revolução. São Paulo Xamã, 1998. 246 p.

BETHELL, L. História da América Latina: a América Latina após 1930: Economia e sociedade. Vol. VI. São Paulo: EDUSP; Brasília, DF: Fundação Alexandre de Gusmão, 2005. 558 p.

CHASTEEN, J. C. América Latina: Uma história de sangue e fogo. Rio de Janeiro: Campus, 2001. 285 p.

ChiAvenAto, J. J. A guerra do Chaco (leia-se petróleo). São Paulo: Brasiliense, 1979. 214 p.

Bolívia com a pólvora na boca. São Paulo: Brasiliense, 1981. 295 p.

CHOQUE, R. Os Aimarás e a questão colonial. In: BONILLA, H. (org.). Os conquistados: 1492 e a população indígena das Américas. São Paulo: Hucitec, 2003. 426 p.

COSTA, A. L. M. C. Muitas Bolívias. Revista Carta Capital. São Paulo: Ed. Confiança, ano XIV, no 476, p. 34 - 35, 26 de dezembro de 2007.

DONGHI, H. História da América Latina. Rio de Janeiro: Paz e Terra, 1975. 325 p.

DORATIOTO, F. Espaços nacionais na América Latina. São Paulo: Brasiliense, 1994. 112 p.

DUSSEL, E. Europa, Modernidade e Eurocentrismo. In LANDER, E. (org) $A$
Colonialidade do saber: Eurocentrismo e Ciências Sociais. Perspectivas latino-americanas. Buenos Aires: CLACSO, 2005. 278 p.

FONT, J. N.; RUFÍ, J. V. Geopolítica identidade e Globalização. São Paulo: Annablume, 2006. 282 p.

GALLUP, J. L.; GAVIRIA, A. e LORA, E. Geografia é destino?. São Paulo: Editora UNESP, 2005. $171 \mathrm{p}$.

GEARY, P. O mito das nações: a invenção do nacionalismo. São Paulo: Conrad Editora do Brasil, 2005. 223 p.

GERAB, K. RESENDE, M. A. A Rebelião de Tupac Amaru. São Paulo: Brasiliense, 1987. (Tudo é História: 119). 739.

GILL, S. Gramsci, materialismo histórico e relações internacionais. Rio de Janeiro: Editora UFRJ, 2007. 448 p.

GUMUCIO, M. P. Breve historia contemporânea de Bolívia. México D.F.: Fondo de Cultura Economica, 1996. 391 p.

HARVEY, D. A produção capitalista do espaço. 2. ed. São Paulo: AnnaBlume, 2006. 251 p.

HOBSBAWM, E. J. Nações e nacionalismo desde 1780 - Programa, mito e realidade. 40 ed. São Paulo: Paz e Terra, 2004. 197 p.

HOFMEISTER, W. Bolívia: a construção da democracia e a evolução do processo político. In: ARAúJO, H. V. de. (org). Os países da comunidade andina. Vol. 1. Brasília: Fundação Alexandre de Gusmão/ IPRI, 2004. 518 p.

KLEIN, H. S. Bolívia: Do período pré-incaico à independência. São Paulo: Brasiliense, 1991. (Tudo é História: 137). 80 p.

LANDER, E. Ciências Sociais: Saberes Coloniais e Eurocêntricos. In: LANDER, E. (org) $A$ colonialidade do saber: Eurocentrismo e Ciências Sociais. Perspectivas Latino-americanas. Buenos Aires: CLACSO, 2005. 278 p. 
LANDER, E. Marxismo, Eurocentrismo e Colonialismo. In BORON, A. A., AMADEO, J., GONZÁLEZ, S. (orgs). A Teoria Marxista hoje: Problemas e perspectivas. São Paulo: Expressão Popular, 2007. 483 p.

MARIÁTEGUI, J. C. Sete ensaios de interpretação da realidade peruana. São Paulo: Expressão Popular/CLACSO, 2008. 330 p.

MARTIN, A. R. Fronteiras e Nações. São Paulo: Contexto, 1992. 91 p.

MELLO, L. I. A. A Geopolítica do Brasil e a Bacia do Prata. Manaus: Ed. Univ. do Amazonas, 1997. $300 \mathrm{p}$.

MERCADO, R. Z. Considerações Gerais Sobre a História da Bolívia (1932-1971). In: CASANOVA, P. G. (org). América Latina: história de meio século. Vol. 2. Brasília: Editora Universidade de Brasília, 1988. 337 p.

MORAES, A. C. R. Bases da formação territorial do Brasil: o território colonial brasileiro no "longo" século XVI. São Paulo: Hucitec, 2000. 431 p.

Território e história no Brasil. São Paulo: Hucitec, 2002. (Geografia: Teoria e realidade: 48. Série "Linha de Frente"). 154 p.

NOVAIS, F. A. Portugal e Brasil na crise do antigo sistema colonial (1777- 1808). $8^{a}$ ed. São Paulo: Hucitec, 2005. 420 p.

PERICÁS, L. B. BARSOTTI, P. (Org.). América Latina: história, crise e movimento. São Paulo: Xamã, 1999. 222 p.
QUIJANO, A. Colonialidade do Poder, Eurocentrismo e América Latina. In LANDER, E. (org) A Colonialidade do saber: Eurocentrismo e Ciências Sociais. perspectivas latino-americanas. Buenos Aires: CLACSO, 2005. 278 p.

SANTOS, L. C. V. G. O império e as repúblicas do Pacífico. Curitiba: Ed. UFPR, 2002. 177 p.

SANTOS, M. A natureza do Espaço. São Paulo: EDUSP, 2002. 384 p.

2003. $204 \mathrm{p}$.

Economia Espacial. São Paulo: EDUSP,

SENA, D. R. de. O Estado do Acre: breve abordagem diplomática e militar. Revista $A$ Defesa Nacional, Rio de Janeiro: BIBLIEX, ano LXXXVIII, no 793, p. 4 - 21, mai/jun/jul/ago 2002.

URQUIDI, V. Movimento cocaleiro na Bolívia. São Paulo: Hucitec, 2004. 223 p.

VIOTTI, M. L. R. As relações Brasil-Bolívia sob o signo da cooperação energética (1930-1990). In: ALBUQUERQUE, J. A. G. (org.). Sessenta anos de política externa brasileira (1930-1990): O Desafio geoestratégico. São Paulo: Annablume/ NUPRI/USP, 2000. 500 p.

WASSERMAN, C. Bolívia: História e identidade. Uma abordagem sobre cultura e a sociedade contemporânea. In: ARAÚJO, H. V. de. (org). Os Países da comunidade andina. Vol. 1. Brasília: Fundação Alexandre de Gusmão/IPRI, 2004. 518 p.

Trabalho enviado em outubro de 2009

Trabalho aceito em dezembro de 2009 
